\title{
The Necessity of Regional Economic Integration: a Lesson for South Asia?
}

\author{
Md. Rajin Makhdum Khan \\ Undergraduate Student ( $3^{\text {rd }}$ Year, $6^{\text {th }}$ Semester), Department of International Relations, Bangladesh University of \\ Professionals, Dhaka, Bangladesh \\ Faizah Imam \\ Undergraduate Student ( $3^{\text {rd }}$ Year, $6^{\text {th }}$ Semester), Department of International Relations, Bangladesh University of \\ Professionals, Dhaka, Bangladesh
}

\begin{abstract}
ASEAN and the European Union have showed this world the privileges regional economic integration provides the states. Although Greece and Italy might be the torchbearers of criticism against regional cooperation and integration, these two organizations tend to be some prime examples of necessity of regional economic integration. This dissertation thus focuses on the privileges and advantages that regional economic integration system and organizations deliver to the states aligned within. With the possible and crucial criticisms on mind, the discussion moves forward analyzing if this system is making the countries perform better economically and advance towards domestic development. The dissertation further intends to find out why the South Asian nations might need similar kind of cooperation and why these countries should act more sensible to make the economic integration possible. While remarking the recommendations, the discussion also draws the barriers and the problems that this region might face in order to integrate their economies or enhance their trades. The core argument of this dissertation therefore lies in analyzing the importance of regional economic integration and liberal economics in this modern world and if the South Asian countries need economic integration to develop their domestic economies. The recommendations are to provide the possible ways to run the process and the drawbacks portion mentions the difficulties and barriers to be faced whilst all of these countries' ongoing strict policies. The argument tries to find out the significance of liberal economics and tribulation of realism in the contemporary world.
\end{abstract}

Keywords: ASEAN, EU, Liberal, Cooperation, Failure, Protectionism

\section{Introduction}

What could be the absolute necessities for a country to follow in order to develop itself in this modern world? The answer to this question might end up being contested by various scholars. Different scholars and intellectuals have different opinions about the ways to live in the world. Countries of different regions and varying resources are not supposed to adopt similar ways in order to develop themselves. While having these thoughts in mind, it is very evident to seek the answer of the question of whether there is a general framework for development. A general framework can also be regarded as a way of policymaking in economic aspects that guarantees development. Certainly there is no criterion or a general framework for development. The two main approaches to explain trade are considered as Liberalism and Mercantilism (Goldstein \& Pevehouse, 2009, p. 278). Mercantilism aligns with realism in the belief that states must protect its interests through exploiting others or anyhow getting benefitted from others (Goldstein \& Pevehouse, 2009, p. 278). Mercantilism believes that states do not need international organizations for their development rather saving its gains is more necessary (Goldstein \& Pevehouse, 2009, p. 278). On the other hand, Liberalism is the alternative approach that promotes creation of international organizations, institutions and norms (Goldstein \& Pevehouse, 2009, p. 278). Liberalism believes in markets and economic globalization through interdependence thus economic integration evidently originates from the trade theory of Liberalism (Goldstein \& Pevehouse, 2009, p. 309). The paper further focuses on exploring the privileges and challenges regional economic integration provides in the modern world. Case studies on ASEAN (Association of South East Asian 
Nations) and EU (European Union) are done on extensive efforts with a view to discovering the reality. It's an attempt to find out a role model if one exists there. Barry Buzan (2016, p. 190) states that "the international economy is the main component and also the main consequence of the rising density and interdependence of the international system." As interdependence exists to a great extent from the opinion of scholars, is it really necessary for every country to follow economic integration and regionalization in order to maintain a perfect balance in the economically interdependent world? The argument thus focuses on deriving information from ASEAN and European Union's experiences and tries to implement its results on the case of South Asian countries.

\section{The Idea of Regional Economic Integration}

Regional integration is a process that provides a peaceful atmosphere where sovereign countries can voluntarily merge their efforts for obtaining mutual concern, regional interests and objectives (Roy \& Dominguez, 2005, p.7). It is supposed to be "a space of conciliation between the creation of regional common goods and national interests, cultures, practices and policies (Roy \& Dominguez, 2005, p. 7)." However the process of integration includes a series of necessary steps (McKay, Armengol \& Pineau, 2004 p. 15). It is firstly necessary to find out what level of integration is wanted (McKay, Armengol \& Pineau, 2004 p. 15). Secondly it is to be found out who are to be the participants of the integration (McKay, Armengol \& Pineau, 2004 p. 15). In the third step, the participants will seek the degree of convergence needed for integration (McKay, Armengol \& Pineau, 2004, p. 15). According to Karen Mingst (2001, p. 225), European Union has followed the path of functionalism in order to bind itself with regional integration. Goldstein \& Pevehouse $(2009$, p. 353) also aligned with Karen Mingst to insist that regional integration is followed by the idea of functionalism. David Mitrany $(1946$, p . 7) stated that "The problem of our time is not how to keep the nations peacefully apart but how to bring them actively together." The idea of integration is thus clarified by the above mentioned statements and definitions. When this integration is done in a specific region consisting of a bunch of specifically cited countries, it is called regional integration (mentioned as the definition of Roy \& Dominguez). Economic integration follows the path of functionalism where "states form supranational institutions and create an economic society to promote free trade and coordinate economic policies (Goldstein \& Pevehouse, 2009, pp. 352-353)." Prime examples of regional economic integration can be found out in the existence of NAFTA (North American Free Trade Agreement), EU (European Union) and APEC (Asia Pacific Economic Cooperation Forum) (Cole, Lyons \& Cary, 1999, p. 70). Although not all scholars admit of ASEAN (Association of South East Asian Nations) as an example of regional economic integration, some acknowledge it as one (Fujita, 2007, p. 3). ASEAN has not yet developed a full regional integral framework as the EU, but it is on the path to do so in the future (Menon and Melendez, 2017). Regional free-trade areas, an aspect of regional economic integration, constitute a major part of world trade (Goldstein \& Pevehouse, 2009, p. 293). A regional trade agreement allows the states to cooperate among themselves and therefore enables them to increase their wealth even if the rest of the world is standing still (Goldstein \& Pevehouse, 2009, p. 293).

Regional economic integration, from the above definitions and statements, can be therefore derived as the creation of an economic community among specifically selected or enlisted countries who willfully participate to form supranational institutions in order to promote free trade and coordinate economic policies among themselves. Integration supposedly challenges the assumption which Realism provides that states are strictly self centered and they long for individual hegemony and power (Goldstein \& Pevehouse, 2009, p. 353). Most policymakers deem that governments should embrace trade because it earns benefits for the nations and also the global economy including the individuals (Moon, 1998, p. 81). The concept suggests that exports provide employments for workers, earnings for business firms and profits that can be utilized for buying imports whereas the imports enhance the well being of civilians as it enables them to acquire more for their money and unavailable domestic resources only to be found out in foreign areas (Moon, 1998, p. 81).

\section{East Asian Miracle and the Tiger Economies}

According to Masahisa Fujita (2007, p. 4), East Asia has had the fastest economic growth from 1970 to 2000. In the 1970s, it was seen that most of the global south countries had enjoyed a real per capita GDP growth of almost 3 percent per annum where the per capita GDP is counted as the simplest measure of economic development (Goldstein \& Pevehouse, 2009 , p. 463). This economic development did not stall only in one region during the 1980s - Asia (Goldstein \& Pevehouse, 2009, p. 463). From 1981 to 1991, China had an annual growth of 7 percent (Goldstein \& Pevehouse, 2009, p. 463).

Before China's sudden growth, some poor states known as Newly Industrializing Countries (NICs) started to attain selfsustained capital accretion whilst having an extraordinary economic growth (Amsden, 2001, p. 131). The export of light 
manufactured goods by these countries generated a solid economic development in the 1980s and early 1990s although it was harmed by the 1997 Asian Financial Crisis (Goldstein \& Pevehouse, 2009, p. 465). Nonetheless the crisis was soon recovered by these countries at a faster pace than the most global south countries (Goldstein \& Pevehouse, 2009, p. 465).

Goldstein \& Pevehouse $(2009$, p. 465) identifies the most successful NICs as the 'four tigers' or 'four dragons' - South Korea, Taiwan, Hong Kong and Singapore. All of these tiger economies were successful in creating development of particular competitive industries and sectors in the world market to make an impact in the world economy as a whole (Goldstein \& Pevehouse, 2009, p. 465). A distributive to all economy was developed by these countries but scholars still engage in debate about whether these tiger economies' achievement is a hoax or it was done under a systematic approach (Goldstein \& Pevehouse, 2009, p. 465). For South Korea, the key resource was iron and coal - a more similar one like the three European giants as we would see in this paper later (Goldstein \& Pevehouse, 2009, p. 465). Hyundai, Kia, Daewoo and other industries of South Korea has generated a huge amount of money from the world market through the export of cars and trucks while the South Korean government showed extreme strictness to the firms that were poorly administered (Amsden, 1989, p. 15). The example is shown by Amsden (1989, p. 15) as the major automobile industries share holder Shinjin's disappearance from the market after the Oil shock of 1970s. Construction firm of Kyungnam and the electronics firm of Taihan group had to be either merged with or sold to Daewoo (Amsden, 1989, p. 15). The South Korean government dictated industrial policy strongly in an attempt to promote and protect the successful industries while showing stringency to the poorly managed firms (Amsden, 1989, p. 15). By the middle of the 1990s therefore, South Korea had earned a per capita income level equal to the per capita income of Spain (Goldstein \& Pevehouse, 2009, p. 465). South Korea later decided to move its production factory to Britain where the costs are lesser and cooperate with the United States to form a free trade area in order to sustain its growth through free economic movement which contributed to its sustainable economic growth (Goldstein \& Pevehouse, 2009, p. 466).

Taiwan also followed a strong industrial policy and it has been enriched with successful electronics and computer firms that have helped Taiwan to possess one of the largest hard-currency reserves of the world (Goldstein \& Pevehouse, 2009, p. 466). Hong Kong, another tiger economy, had its rise to a developed economy through its electronics and other light industries but most contribution came from the banking and trade between Southern China and the rest of the world (Goldstein \& Pevehouse, 2009, p. 466). Singapore is geopolitically considered a trading hub and similar to Hong Kong, it also drew MNCs to set up headquarters there on the basis of its trading hub identification (Goldstein \& Pevehouse, 2009, p. 466). South Korea and Taiwan both have sprinted towards a higher economy despite their political conflicts at the borders (Goldstein \& Pevehouse, 2009, p. 466). Hong Kong and Singapore are merely city-states and are considered essential as trading ports and financial centers (Goldstein \& Pevehouse, 2009, p. 466).

Other Southeast Asian countries - Thailand, Malaysia and Indonesia have endeavored to follow the track of these four Asian tigers from the 1980s (Goldstein \& Pevehouse, 2009, p. 466). Under Deng Xiaoping in 1976, China adopted capitalism as the economic institution system through individual farming of peasants and allowing foreign direct investment through an open trading system (Goldstein \& Pevehouse, 2009, p. 467). China's economic growth has been miraculous comparing to the previous times since the adoption of these new policies (Goldstein \& Pevehouse, 2009, p. 467). Inflation and corruption erupted revolutions and later subsequent economic reformations contributed to a 12 percent annual growth of China by 1994 (Goldstein \& Pevehouse, 2009, p. 467). China was able to sustain itself during the 1997 Asian Financial Crisis when most of the countries succumbed to depression and by 2006 it had an annual growth of 10 percent under the rule of invigorated leaders like Hu Jintao (Goldstein \& Pevehouse, 2009, p. 467). The economic development of the four tigers and the three other Southeast Asian states in the late twentieth century alongside the Chinese economic revival after the 1980 s is collectively termed as the East Asian Miracle.

\section{The Path that Realism Shows}

Liberals perceive peace as the general state of affairs (Burchill, 2001, p. 33). Mercantilism, the economic idea of Realism, is intimately tied with the emergence of modern sovereign state (Jackson \& Sørensen, 1999, p. 178). It is the first view of trade other than liberalism (Goldstein \& Pevehouse, 2009, p. 278). Mercantilism bases its idea on creating a strong powerful state with great prowess (Jackson \& Sørensen, 1999, p. 179). It is however the oldest approach to international political economy (Mingst, 2001, p. 184). According to the traditional mercantilists, "A Surplus balance of payments is critical to protect the national interest (Mingst, 2001, p. 185)." Mercantilists view economy as 'low politics' (Steans, Pettiford, Diez \& El-Anis., 2010, p. 65). As the features of high politics, war and diplomacy determine economics (Mingst, 2001, p. 185). The view of trade and interdependence is seen through two visions (Nye \& Welch, 2015, p. 275). These two visions are 
conveyed as 'zero-sum' game and 'non-zero sum' game (Nye \& Welch, 2015, p. 275). Mercantilists view trade as a zerosum game where one side gains the amount the other side loses (Jackson \& Sørensen, 1999, p. 178). Liberals view trade as a non-zero sum game where both parties win and thus make it a positive sum-game (Jackson \& Sørensen, 1999, p. 183). Another aspect suggests non-zero sum game where both parties lose and therefore make it a negative sum game (Nye \& Welch, 2015, p. 275). The idea of interdependence and trade therefore varies within these two perceptions. Mercantilists view trade and interdependence skeptically while liberals view them as beneficiary according to the perceptual varieties.

Mercantilism can be followed in two ways (Jackson \& Sørensen, 1999, p. 178). The first way is called 'benign mercantilism' where states only look further to save and protect their national interests keeping the realist assumption intact that individual development is the key goal according to Jackson \& Sørensen (1999, p. 178). The second one is called 'aggressive or malevolent mercantilism' by Jackson \& Sørensen (1999, pp. 178-179) where states attempt to exploit other states or international economy through protecting its own interests, gaining the maximum advantage and creating an expansionary strategy to be more powerful.

According to Goldstein \& Pevehouse (2009, p. 279), the mercantilist view stands correct as in international trade, one or the other party benefits more from a trade. Realism thus shows the path of protectionism in an extensive aspect as it contradicts with the ideas of liberalism (Goldstein \& Pevehouse, 2009, p. 287). Under the conditions of protectionism, states seek to benefit the domestic industries or companies through preventing import of competing foreign goods (Goldstein, 1986, p. 161). When a government follows protectionism, it might be a fact that the policy was taken owing to a lobbying by a domestic industry (Goldstein \& Pevehouse, 2009, p. 287). It is however sometimes evident that temporary protectionism for infant industries has been proved to be successful in the cases of South Korean automobile manufacturers (Goldstein \& Pevehouse, 2009, p. 287). The core component of realism found in the idea of protectionism is the fear of the state which can be derived from the aforementioned statements. Realism views the world surrounded by anarchy and thus the states fear each other and distrust prevails (Steans, Pettiford, Diez \& El-Anis., 2010, p. 57). Deriving from this, from the perspective of realists, the world is in an anarchic condition and the states vie with each other for power and they are always indulged in a vicious quest of maneuvering power (Steans, Pettiford, Diez \& El-Anis., 2010, p. 57). Protectionism mainly covers four aspects or versions which have been or are still being followed by various states (Goldstein \& Pevehouse, 2009, p. 288). The first is known as a tariff, which defines a tax entailed upon certain imported goods to enter the buyer country (Goldstein \& Pevehouse, 2009, p. 288). The second one can be derived as non-tariff barriers which imply a limit on imports by forming a quota system and binding import of the good to a specific or limited number (Goldstein \& Pevehouse, 2009, p. 289). The third way is called the system of subsidizing where the government provides an amount of security money or resources or somehow subsidize the loss faced by an industry to compete with the importer foreign industry (Goldstein \& Pevehouse, 2009, p. 289). Subsidies sometimes make the domestic industries complacent and this inflicts the industry's competitiveness to a great extent and it is more or less ineffective to make a domestic industry win against a foreign importer (Goldstein \& Pevehouse, 2009, p. 289). The fourth way is known as restriction and regulations which affect the foreign importer to face many restrictions and difficulties to transfer or market his product (Goldstein \& Pevehouse, 2009, p. 289). Mercantilism was previously known as Economic nationalism in the late 1800s and early 1900s (Steans, Pettiford, Diez \& El-Anis., 2010, p. 66-67). Economic nationalism had previously followed a strict posture of protectionism and the examples of protectionism can be found in the 'beggar thy neighbor' policy taken by the United States government prior to the World War II (Steans, Pettiford, Diez \& El-Anis., 2010, p. 67).

Another aspect of mercantilism is autarky which makes the weak states prevent becoming dependent on stronger ones (Goldstein \& Pevehouse, 2009, p. 286). Autarky is the idea where states produce every good by itself and it denies trade to obtain self-reliance (Goldstein \& Pevehouse, 2009, p. 286). The state of Albania had followed autarky and it found itself economically naive in the early 1991 when its autarky had ended due to the fall of communist rule (Goldstein \& Pevehouse, 2009, pp. 286-287). China under Mao Zedong and the current flows of North Korea follow self-reliance or autarky (Goldstein \& Pevehouse, 2009, p. 287). Autarky has been proven ineffective historically and evidence of Albanian development after 1991 and the Chinese economic miracle after opening up in the 1980s shows the inefficiency of autarky (Goldstein \& Pevehouse, 2009, p. 286-287). The idea of autarky therefore is derived from mercantilism that the strong states exploit the weaker states through trade and instead of trading to gain comparative advantage, it rather suggests on obtaining selfreliance. The aspects of comparative advantage are discussed in the latter portion. Protectionism does not always cause harm (Goldstein \& Pevehouse, 2009, p. 289). Most often it helps producers and affects customers (Goldstein \& Pevehouse, 2009 , p. 289). One problem of protectionism suggests that it makes industries ineffective and less competitive which in turn 
affects the state (Goldstein \& Pevehouse, 2009, p. 289). However, some scholars suggest that temporary protectionism can stabilize one industry which benefits the domestic producers and this thought is proved by the example of Harley Davidson industries (Goldstein \& Pevehouse, 2009, p. 289). The US government had subsidized the Harley Davidson Motorcycle company by imposing tariffs upon Japanese motorcycles to compete with the Japanese manufacturers where the company was threatened with losing its market to the Japanese industries and further it improved its quality (Goldstein \& Pevehouse, 2009, p. 289). This helped the company to sustain itself in the market and a domestic industry was saved from going astray.

This is the path that Realism shows with the ideas of autarky and protectionism alongside the zero sum measurement. The aforementioned statements show that protectionism does not deny trade but it obviously hampers the harmonious idea of trade. Realism's skeptical view is not shared by most but internalized by many countries in the contemporary world through protectionism (Moon, 1998, p. 86). Many forms of protectionism have been introduced in the world in the past decades as governments have reacted positively to the requests of threatened industries (Moon, 1998, p. 86). Even the United States and its newly elected President Donald Trump promoted an idea of 'Buy American' which was evidently a sign of protectionist policy (Waldmeir and Donnan, 2017). Mercantilists are afraid that massive amount of imports allow foreigners to consume more employment and revenues from production that would have gone to citizens of the home country if trade was not allowed (Moon, 1998, p. 84). From an economic nationalist or mercantilist view, a regional free trade area is seen as a source that augments a region's prowess at the losing or expense of other areas of the world (Goldstein \& Pevehouse, 2009, p. 293). Autarky's history leads us to the firm belief that it's inefficiency and its experience is tormented with failure. Thus it does not remain as an option for a country's economic development. With these aspects of this discussion, a question evidently appears. The question can be identified as - 'Does Liberalism and Regional Economic Integration provide more amount of benefits than protectionism and mercantile exploitation?'

\section{European Union}

What was Europe doing back in the previous centuries? Europe has been the birthplace of Protestantism - a counter revolution to the Holy Roman Empire's religious-political hegemony; the bloody Thirty Years War; the French Revolution; the Industrial Revolution and Capitalism; 1848 People's Revolutions; the ideologies of Marxism, Fascism, Nazism, Social Darwinism, Racial Greatness, Liberalism and modern statehood; Colonialism and Imperialism; the most contentiously gory wars of all time - World War I and World War II (Mason, 2011). During the Cold War period after the World War II, Europe was divided into two parts - the capitalist bloc and the communist bloc, the first led by the United States of America (USA) and the latter one led by the United Soviet Socialist Republic (USSR) or, more clearly known as the Soviet Union (Mason, 2011, p. 143). The Cold War began centering on the German city of Berlin where a wall was constructed and it demarcated the borderline of the two blocs (Mason, 2011, p. 143).

With these new structural conditions and ruined geographical situations, Europe's capitalist bloc attempted to demonstrate the century-old idea of a united Europe of Immanuel Kant and Jean-Jacques Rousseau into reality through forming institutions and trading communities (Mingst, 2001, p. 196). According to David S. Mason (2011, p. 179), the EU's current embodiment is the successor of an idea occasionally called the European Common Market. Destructed by the vicious war, Europe was assisted with aid from the United States through the initiation of Marshall Plan (Goldstein \& Pevehouse, 2009, p. 354). Two French leaders Jean Monnet and Robert Schuman initiated the plan of executing the idea of functionalism which would tie the states altogether politically for economic interests and collective development eventually preventing war and competition among themselves (Goldstein \& Pevehouse, 2009, p. 354). Schuman planned to integrate German and French steel and coal industries as coal and steel was deemed important for European recuperation (Goldstein \& Pevehouse, 2009, p. 354). The integration formed a single framework able to efficiently use the two states' necessary resources and eventually the Schuman Plan in 1952 led the emergence of European Coal and Steel Community (ECSC) (Goldstein \& Pevehouse, 2009, pp. 354-355). ECSC consisted of Germany and France - the two previously mentioned countries and Italy (the third huge industrial country of continental Europe), Belgium, Netherlands, Luxembourg (altogether known as BENELUX) (Goldstein \& Pevehouse, 2009, p. 355). Previously in his famous 'Iron Curtain' speech, Winston Churchill wished for a United Europe but he did not wish the Great Britain to be included in the union rather he focused on the seventy five years power feud between Germany and France to be eliminated (Mason, 2011, p. 180). The incentive of the formation of ECSC was followed by an idea where elimination of barriers to trade of coal and steel was at the core of the formulation (Mason, 2011, p. 181). The ECSC followed a core liberal assumption that the best producer owns the market and a fully competitive market should emerge in order to have the best outcome of all the producers. A quality 
production could save the downed economy of the Europe and this is what was at the focus of this integration. Coal and steel were backbones of the industrial economies of Europe and abolition of trade barriers would thus provide efficient production of these two products which might create a path for European recovery (Mason, 2011, p. 181). The facilitation of this process was organized by the 'High Authority' - a supranational controller of the coal and steel industries of all these six states with its headquarters in Luxembourg (Mason, 2011, p. 181). Representation from all states was confirmed and decisions were taken on the basis of majority votes where it could create norms going against interests of one or more country, but the liberal idea bound everyone to that obligation (Mason, 2011, pp. 181-182). Alongside administering production, marketing and prices, the administration also aided weaker producers with modern technologies, readapting and conversion (Mason, 2011, p. 182).

However, in 1957, the same six countries signed the Treaty of Rome that created two new organizations - European Economic Community (EEC) and the EURATOM (Mingst, 2001, p. 196). The reason behind this was probably ECSC's huge success in both economic and political aspects (Mason, 2011, p. 182). The aim was directed at free movement of capital and labor within the member countries (Mason, 2011, p. 182).

The triumph of EEC ultimately led to the integration of all these institutions in 1967 (Mason, 2011, p. 182). The integrated institutions were named 'European Community (EC) and within 1968, all internal tariff barriers were eliminated (Mason, 2011, p. 182). In between mid 1960s and mid 1980s, economic development was dormant which ultimately led the institutions to some reformations (Mingst, 2001, p. 197). As a part of this reformation, the original six countries saw expansion of the community - Denmark, the United Kingdom and Republic of Ireland attached to the EC in 1973; Greece in 1981; Portugal and Spain in 1986; and Austria, Finland and Sweden in 1995 (Mingst, 2001, p. 197). The greatest expansion was seen in 2004 with the joining of 10 new countries to the European Union - Poland, Czech Republic, Slovakia, Hungary, Slovenia, Estonia, Latvia, Lithuania, Malta and Cyprus (Goldstein \& Pevehouse, 2009, p. 364). Bulgaria and Romania joined the organization in 2007 (Goldstein \& Pevehouse, 2009, p. 366).

Political union of these countries was sought and through the signing of Maastricht Treaty in 1992, the formal emergence of European Union happened replacing the previously European Economic Community where the founding of common foreign and defense policies, a single currency and a regional central bank were at the focus of the discussion (Mingst, 2001, p. 197). This treaty ultimately made the European Union a complicated organization with three key pillars (Mingst, 2001, p. 198). As Karen Mingst (2001, p. 200) put up many questions about the European Union's ultimate future and its possibilities, it can be asserted that only the economic union was well desired by all the member states. The want of a political union made these things diversely complicated. The questions of ethnicities, integrating key policies and the question of what kind of integration therefore appeared at the face of European Union (Mingst, 2001, p. 199). One example of the problem of political union can be drawn from the event of 2008, when Kosovo declared its unilateral independence from the former Yugoslavia dividing the EU into two parts (Simms, 2014, p. 521). 22 member states affirmed the recognition whereas Greece, Cyprus, Spain, Romania and Slovakia refused to recognize Kosovo owing to their own demographic diversity and separatist rebel group problems (Simms, 2014, p. 521).

\section{Wonder at Hand?}

The positive sides of this economic integration are many. From the theoretical analysis and explanations from the previous parts, we can say that free trade and competition makes the market better and the most effective one. When there is competition among the sellers or the producers, they have to perform the best in order to survive in the market. He, who fails to intensify and improvise his products at the best of costs, fails to survive in the market. Survival of the fittest in this case is exemplary. Free trade also contemporizes us with the concept of comparative advantage. Comparative advantage means specialization of production according to the distribution of resources. States do not possess the similar natural resources to produce certain goods (Goldstein \& Pevehouse, 2009, p. 282). Thus in order to maximize the all over creation of wealth, every state individually should focus on producing certain goods that delivers it a comparative advantage and trade with others in order to fulfill the deficit of other necessary goods (Goldstein \& Pevehouse, 2009, p. 282). The European Union or say any regional economic integration is therefore the tool to promote free trade and have comparative advantage of every country in a single market without any trade barriers or tariffs. The idea of infinite resources in economics has long gone by and it is now universally acknowledged that resources are finite in this world. In this world of finite resources where all individual countries possess different sorts of natural resources, comparative advantage is the best solution for all. European Union specializes on doing that. Through the promotion of comparative advantage, it also eliminates the less competitive and less productive sellers who do not stand to deliver the best services and utility for the combined European 
citizens. Goldstein \& Pevehouse (2009, pp. 282-283) explains the benefit of comparative advantage through the example of Saudi Arabia and Japan and the products of oil and cars. Saudi Arabia has a specialization in oil production whereas Japan can efficiently produce cars. Now if Saudi Arabia delivers oil to Japan through free trade and Japan trades cars with Saudi Arabia, Japan can fulfill its lack of oil production and Saudi Arabia's demand for cars also gets complied. If Saudi Arabia, instead of trading oil and cars, intends to produce cars by themselves, they will be able to produce it, but it would cost a lot of money. If Japan wants to produce oil, Japan would also face an economic downfall overall because they don't have the resources and the industries to produce the goods at the quality of what their opposites can and also at the price or cost of Saudi Arabia. So trading is the best option here to avoid the cost inefficiency. Similarly, if Germany supposedly is better at producing cars or electric utilities, it is somewhat poor in raw materials. If the Baltic countries can export their raw materials to Germany without a tariff barrier, the Baltic countries can have a good amount of profit at a less amount of selling price to Germany. Later these Baltic countries can have the cars that have been produced by Germany. If the Baltic countries moved towards producing cars, a secondary level of industry, their economy might succumb to an economic destruction. Thus this idea of comparative advantage is realized thoroughly in the European Union and EU actually makes countries better through free trade, utilization of finite resources and efficiency of producers through providing perfectly competitive market.

However, according to Daron Acemoglu and James A. Robinson (2013), inclusive institutions are the key to sustainable economic development. Many countries have developed for a limited time with an imperfect growth that has later experienced a sudden downfall. European Union, through its transparent bureaucracy and structures, provides an inclusive economic and political institution system for all the EU member states' citizens making them European citizens. This is also a positive aspect of why regional economic integration with an inclusive and transparent institution system is necessary. Interests in the European Union are therefore intertwined and no country dares to act on its own, making the countries care for others for the sake of their own interests. Participation of all countries are necessary with a voting system and without one country's ratification, the decisions do not get completed and every single member of the union matters in the decision making process.

In the events of environmental issues and other aspects, the multilateralism of EU is very effective to save everyone's interests and thus to act as a single actor. We have seen the emphasis of a European integration in the words of Rousseau and Kant. George Kennan (Simms, 2014, p. 381) insisted that "If there is no real European integration and if Germany is restored as a strong and independent country, we must expect another attempt at German domination. If there is no real European federation and if Germany is not restored as an independent country, we invite Russian domination... This being the case, it is evident that the relationship of Germany to the other countries of western Europe must be so arranged as to provide mechanical and automatic safeguards against any unscrupulous exploitation of Germany's pre-eminence in population and in military-industrial potential." His emphasis on a European integration for preserving peace in Europe was voiced in the 2012 Nobel Peace Prize winning of the European Union (Epatko, 2012). The historical rivals France and Germany cooperated with each other for about sixty years and no further conflict ever escalated between them. Peace could be retained because of this economic integration and integrated development of the two countries altogether. If these two countries had to compete against each other for economic superiority (as economy is the key instrument that can guarantee defense, welfare and all other expenditures), the scenario would have been similar to the Cold War. When included in an integrated economy, the interests of the member states are interweaved and all countries aim for integrated development, leaving the idea of individual betterment aside.

\section{Fate of the Forlorn Sons: Story of Greece, Ireland and Others}

Europe faced a big crisis in 2010 , when Greece was hit by a financial crisis frightening it with a permanent destabilization (Mason, 2011, p. 189). Greece had to cut its expenditure on welfare, social services and retired employees to overcome its debts (Mason, 2011, p. 189). This infuriated the public of Greece and the EU allotted 80 billion Euros to stabilize Greece (Mason, 2011, p. 189). This bailing out of Greece was also skeptically assumed by the leaders in different EU states as pointing out to why would the Germans, the British, the French and the others would have to compensate for the vice of the Greeks.

The collective effect of the economic crisis, governmental ineptitude, lower tax submissions, organized tax fudging and huge euro-dominated debts swelled owing to lower interest rates by the monetary union that affected the 'PIIGS' - Portugal, Ireland, Italy, Greece and Spain (Simms, 2014, p. 525). While Greece scrambled over the social service cuts, Ireland was more submissive to the EU austerity measures in a hope that it would bail them out if it cut its expenses (Simms, 2014, p. 
525). Portugal, Italy and Spain stood on the brink of collapse while there was also dubiety against the core country of Belgium (Simms, 2014, pp. 525-526). Owing to these events, the EU was at a diffident position and by 2011 Europe had began to experience a financial meltdown (Simms, 2014, p. 526).

Euroskepticism also mounted in the countries of Hungary, the UK, the Netherlands, and France as Janos Kadar conquered Hungary's politics but Geert Wuilders failed to garner votes through populist agendas of EU exit (Boffey, 2017). As such, economic integration is currently threatened with the ideas of self-interest, individual development and survival of individual. The Europe, which was pioneering and making others learn about collective development and free trade, now seems to be in decay with a protectionist agenda in advent.

\section{The Progress of ASEAN}

ASEAN is considered as the leading organization in the Asia Pacific for Free Trade Area (FTA) formation (Tangkitvanich \& Rattanakhamfu, 2017). The ASEAN FTA was initiated in 1993 and the year 2015 saw the emergence of ASEAN Economic Community (AEC), a similar version of EEC (Tangkitvanich \& Rattanakhamfu, 2017). While ASEAN's success in managing regional conflicts and organizing regional cooperation has been very much applauded, its EC still has a long way to go in order to fulfill the procedure (Tangkitvanich \& Rattanakhamfu, 2017). In 1967, ASEAN was formed by Indonesia, Singapore, Malaysia, the Philippines and Thailand (Blaxland, 2017). It was expanded to consisting of 10 member states during the 1980s and the 1990s - Brunei, Vietnam, Cambodia, Laos and Myanmar as the new members (Blaxland, 2017).

Till now from economic perspective and for development purposes, ASEAN has been triumphant in only one aspect elimination of tariff barriers (Tangkitvanich \& Rattanakhamfu, 2017). The signing of CEPTA (Common Effective Preferential Tariff Agreement) in the 1990s ultimately led to the reduction of 99 percent tariff lines to 0 (Tangkitvanich \& Rattanakhamfu, 2017). However the existence of Thai-Cambodian border skirmishes and other interregional conflicts makes the future of ASEAN look more pale (Acharya, 2011). According to Amitabh Acharya (2011), surviving is not the same as thriving and till now ASEAN states have some conflicts with each other going on, a very unusual practice than the EU.

The 1997 Asian Financial Crisis hit the East Asian countries hard; although China was able to escape the negative impacts of the crisis, the Asian crisis left Thailand, South Korea and Indonesia incapable of defending their currencies from collapse (Drysdale, Armstrong, Ascione, Manuel \& Mowbray-Tsutsumi, 2016). This crisis taught the East Asian countries a proper lesson and thus these economies moved toward amassing a huge foreign exchange reserve of USD 11 Trillion known as - Chiang Mai Initiative (CMI) (Drysdale, Armstrong, Ascione, Manuel \& Mowbray-Tsutsumi, 2016). The East Asian countries successfully survived the 2008 financial crisis and till now no country has been forced to draw funds from the CMI (Drysdale, Armstrong, Ascione, Manuel \& Mowbray-Tsutsumi, 2016). Although the fund consists of USD 240 Billion as of 2012, it is not sufficient to overcome a financial crisis (Drysdale, Armstrong, Ascione, Manuel \& Mowbray-Tsutsumi, 2016).

The dominance of the East Asian Newly Industrializing Countries has grown by time to time. They have dominated the manufacturing and export of products for the less developed countries (Haggard, 1995, p. 46). Developing countries can be enjoined through a group or integration and deep integration agenda mostly dominates the group of advanced developing countries - in this case the East Asian region (Haggard, 1995, p. 8). Korea, Taiwan, Hong Kong, Singapore, Malaysia, Indonesia and Thailand (Only the Philippines stands out) has been following an export oriented development trajectory since the 1990s following the path of the four Asian Tigers (Haggard, 1995, p. 9). The export success of these countries has ultimately bred conflicts with their major trading partners - specially the USA and this success has undoubtedly moved them upwards in the course of economic development (Haggard, 1995, p. 9).

The colonial experience is not a forgotten one for these countries yet overcoming the colonial exploitation that left them unstructured, uncivilized and destructed was possible for them. Despite the political turmoil and scarcity of resources and proper institutions, the lesson that these countries learned and the quick counter they poised towards the Western and developed countries is undoubtedly a phenomenal experience for the economic history of the world.

ASEAN now stands with a collective GDP of USD 2.5 trillion and Intra-ASEAN trade is 545 billion USD (Blaxland, 2017). However, the limited success of the AEC (only tariff reduction) makes everyone including scholars and analysts very much skeptic and doubtful about its success in the future. It is to be mentioned that only one of the ASEAN countries - Singapore belongs to the Asian tigers group. Rest of the countries are still counted as emerging economies rather than advanced developed economies. 


\section{South Asian Dilemma}

The fear of losing national industries and home grown companies in the domestic market itself has been evident in the previous discussions and the procedure of following 'protectionism' has also been mentioned. When governments panic due to the appearance of new sellers from outside countries and their efficiency of providing much better quality than the domestic sellers, they impose tariffs on the specific products which are needed to protect the domestic businessmen or companies. The trade dilemma of India has been regularly hampered by this fear and protectionism is a regular activity of India being the world's most eminent safeguard measures user (Park, 2016).

India is a similarly large state like China and it therefore earns a special attention (Goldstein \& Pevehouse, 2009, p. 470). India's yearly growth in 2003 was measured to be around 8 percent (Goldstein \& Pevehouse, 2009, p. 471). The South Asian economic integration lacks pace because of the existence of historical rivals of Pakistan and India which has underpinned tariff barriers between these two states (Iqbal \& Nawaz, 2016). As previously explored in the paper, comparative advantage benefits the smaller countries relatively more as the bigger the country, the more the resources. Despite being a huge country, India aimed at cooperating with Pakistan through providing it the MFN (Most Favored Nation) status in 1995 and Pakistan did not cooperate until 2011 (Iqbal \& Nawaz, 2016). While India has recently strained its relations with Nepal, it moved forward to economically cooperate with Bangladesh (Maini, 2016). Bangladesh therefore imports energy and power production from India (Maini, 2016). Smaller countries of this region - Bhutan, Nepal and Sri Lanka can also benefit from the powerhouse of this region - India. The recent developments in Bangladesh-India trade relations provide the proof that both countries are opening up to bilateral trade denying protectionism (Maini, 2016). Under the current governments, Bangladesh and India have significantly advanced on trade, investment and communication cooperation (Zaman, 2017). The barrier which comes in front now is the stringent Indo-Pak relations.

\section{What Lies Ahead}

The discussion on the historical evolution of the European Union shows us one similarity or continuity - the expansion of the union. Time and again, we can see that new members for the union have arrived. The Union started with only six members and currently it consists of 28 members. Although the Great Britain is leaving the union making it a union of 27 countries through the procedure of Brexit Referendum, more countries are still interested to be included in the union (Nougayrède, 2017). In 2013, Croatia was the last country to enter the union (Bilefsky, 2013). In 2007, Ukraine was interested in reforming its economics and civil society to deliver a membership bid for the union (Simms, 2014, p. 520). In April 2008, Macedonia was promised to be counted for an invitation if it could have ended its dispute with Greece (Simms, 2014, p. 521). Bosnia and Montenegro alongside Ukraine and Georgia were also told that new membership in the future for these countries is possible (Simms, 2014, p. 521). Bosnia and Montenegro were thus invited to start intensified dialogues to prepare for a future membership through structuring the country (Simms, 2014, p. 521). Turkey has also been very keen to join the union although the Europeans have been cynic about the Turkish inclusion (Mowat, 2016). George Friedman's prediction $(2010$, p. 116) however seems irrelevant now as it was the UK, not Germany who sent troops to Estonia to engage in power politics and deter the Russian federation (Willetts, 2017).

The argument for EU to consider it as a wonder of economic development can be found in the British insertion into the union. In 1950, Britain was plagued with expenditure on international crises (Simms, 2014, p. 416). The World War II left the UK economically depressed and this was not the ideal time to engage in liberating people from the clutch of communism. Expenditures on defense fearing a Soviet invasion of Europe, the UK had to cut its domestic spending (Simms, 2014, p. 416). The massive defense expenditure caused a balance-of-payments crisis in the UK and saw the Minister of Labor, Aneurin Bevan resigning from the office (Simms, 2014, pp. 416-417). In 1956, the loss of the Suez Canal also caused a Pound Sterling crisis in Britain and France was also hit hard by the loss which ultimately provided an impulse to European integration project (Simms, 2014, p. 426). In 1973, after the Yom Kippur War between the Arabs and Israel, the oil producer Arab countries decided to reduce their oil production and announced an oil embargo against the collaborators of Israel (Simms, 2014, p. 456). This financial recession of 1973 ultimately saw Britain devastated and it then realized that it couldn't walk the economic path alone. Great Britain's great realization and eventual inclusion into the union gives us ample thoughts to recognize the positive side of European economic integration or in simple words, the European Union. 
The future of $A E C$ is very much ambiguous and it is very tough to be predicted as explained in the previous parts. However, South Asian economic integration might see sunrise as Bangladesh and India, both the countries are moving towards economic cooperation which in turn may inspire the other countries. SAARC is not the only hope in the region as the desire is also evident in the newly formed BIMSTEC. Narendra Modi's arrival in India is also inspiring new South Asian regional and global integration (Gupta, 2015).

\section{Conclusion}

It is very much evident from the history that the reason of forming an economic union eliminating trade barriers was the lesson learnt from the harrowing memory of the Second World War that left the whole Europe devastated both economically and structurally. The trade union helped it recover its economy and through the economic integration, it was about to fight back in this world. But looks like people tend to forget the mischief and sorrows of themselves which ultimately leads them to be suicidal about the peace that they had garnered owing to that sorrowful experience of mischief. Similar thought was explored by Brendan Simms (2015, pp. 508-509) - "As the memory of the Second World War and the Soviet threat faded, peoples of Europe were becoming increasingly suspicious of EU 'bureaucracy', and sceptical of the need to sacrifice their national sovereignty". This thought might have been criticized by many but the thought looks a very real and prudent one as we have already witnessed the Brexit or Great Britain's exit from the European Union. The economic union may embrace decay in the coming days owing to the growing skepticism about the long peace it has provided but it might be too late to realize the benefits the union had provided. The final line thus may surprise all - no EU member has fought against each other in a violent armed conflict so far but things don't look like to acknowledge this wonderful fact. However, the tribulation of Realism doesn't seem to be evident rather regional economic integration creates regions as individual states and the realist view on regional integration is rather found to be prominent in the existence of EU and ASEAN from the collected information as countries do not intend to scamper towards an integrated world economy, rather regional cohesion for selfeconomic development through realizing comparative advantage.

\section{References:}

[1] Acemoglu, D., \& Robinson, J. (2013). Why Nations Fail: The Origins of Power, Prosperity and Poverty. London: Profile Books Ltd.

[2] Acharya, A. (2011). ASEAN in 2030. East Asia Forum. Retrieved 25 August 2017, from http://www.eastasiaforum.org/2011/02/15/asean-in-2030/

[3] Amsden, A. (1989). Asia's next giant: South Korea and Late Industrialization. New York: Oxford University Press.

[4] Amsden, A. (2001). The rise of "The Rest": Challenges to the West from Late-Industrializing Economies. New York: Oxford University Press.

[5] Bilefsky, D. (2013). Joyous Croatia Joins Europe Amid a Crisis. The New York Times. Retrieved from http://www.nytimes.com/2013/07/02/world/europe/croatia-joins-european-union.html

[6] Blaxland, J. (2017). After 50 years, is ASEAN retiring or just getting started?. East Asia Forum. Retrieved 27 August 2017, from http://www.eastasiaforum.org/2017/08/04/at-50-years-old-is-asean-retiring-or-just-gettingstarted/

[7] Boffey, D. (2017). Rising Euroscepticism 'poses existential threat to EU'. The Guardian. Retrieved from https://www.theguardian.com/politics/2017/mar/03/brexit-has-put-other-leaders-off-wanting-to-leave-says-ecvice-president

[8] Burchill, S. (2001). Liberalism. In S. Burchill, R. Devetak, A. Linklater, M. Paterson, C. Reus-Smit \& J. True, Theories of International Relations (2nd ed.). Houndmills, Basingstoke, Hampshire: Palgrave.

[9] Buzan, B. (2016). People, States and Fear: An agenda for International Security Studies in the Post-Cold War Era. Colchester: ECPR Press.

[10] Cole, K., Lyons, R., \& Cary, D. (1999). Regional Economic Integration. The Review: A Journal Of Undergraduate Student Research, 2(14).

[11] Drysdale, P., Armstrong, S., Ascione, B., Manuel, R., \& Mowbray-Tsutsumi, J. (2016). Asia and the next financial crisis. East Asia Forum. Retrieved 31 August 2017, from http://www.eastasiaforum.org/2016/02/22/asia-andthe-next-financial-crisis/

[12] Epatko, L. (2012). Why Did the European Union Win the Nobel Peace Prize?. PBS NewsHour. Retrieved 31 August 2017, from http://www.pbs.org/newshour/rundown/european-union/ 
[13] Friedman, G. (2010). The Next 100 Years: A Forecast for the 21st Century. London: Allison \& Busby.

[14] Fujita, M. (2007). Globalization, Regional Integration and Spatial Economics: An Introduction. In M. Fujita, Regional Integration in East Asia: From the Viewpoint of Spatial Economics. Houndmills, Basingstoke, Hampshire: Palgrave Macmillan.

[15] Goldstein, J., \& Pevehouse, J. (2009). International Relations (8th ed.). Noida: Pearson Education Inc.

[16] Gupta, S. (2015). Modi can lead South Asia's regional and global integration. East Asia Forum. Retrieved 5 September 2017, from http://www.eastasiaforum.org/2015/07/06/modi-can-lead-south-asias-regional-andglobal-integration/

[17] Haggard, S. (1995). Developing nations and the politics of global integration. Washington, D.C.: Brookings Institution.

[18] Iqbal, N., \& Nawaj, S. (2016). Why has SAFTA failed to boost Pakistan-India trade?. East Asia Forum. Retrieved 3 September 2017, from http://www.eastasiaforum.org/2016/03/19/why-has-safta-failed-to-boost-pakistanindia-trade/

[19] Jackson, R., \& Sørensen, G. (1999). Introduction to international relations. New York: Oxford University Press.

[20] Maini, T. (2016). India-Bangladesh economic ties gain momentum. East Asia Forum. Retrieved 3 September 2017, from http://www.eastasiaforum.org/2016/03/18/india-bangladesh-economic-ties-gain-momentum/

[21] Mason, D. (2011). A Concise History of Modern Europe (2nd ed.). Plymouth: Rowman \& Littlefield Publishers, Inc.

[22] McKay, J., Armengol, M., \& Pineau, G. (2005). Regional economic integration in a global framework. Frankfurt am Main: European Central Bank.

[23] Menon, J., \& Melendez, A. (2017). (Re)realising the ASEAN Economic Community. East Asia Forum. Retrieved 5 August 2017, from http://www.eastasiaforum.org/2017/08/24/rerealising-the-asean-economic-community/

[24] Mingst, K. (2001). Essentials of international relations (2nd ed.). New York, Ny: W.W. Norton \& Company, Inc.

[25] Mitrany, D. (1946). A Working Peace System. London: Royal Institute of International Affairs.

[26] Moon, B. (1998). Controversies in International Trade. In M. Snarr \& D. Snarr, Introducing Global Issues. Boulder, Colorado: Lynne Rienner Publishers, Inc.

[27] Mowat, L. (2016). It will happen in seven years: Turkey believes it will join the EU by 2023. Express. Retrieved from http://www.express.co.uk/news/world/702009/Turkey-join-European-Union-2023

[28] Nougayrède, N. (2017). Britain is leaving the EU - just as Europe is on the up. The Guardian. Retrieved from https://www.theguardian.com/commentisfree/2017/jun/18/brexit-europe-eu-golden-decade-merkel-macron

[29] Nye, J., \& Welch, D. (2015). Understanding Global Conflict and Cooperation: An Introduction to Theory and History (9th ed.). Noida: Pearson India Education Services Pvt. Ltd.

[30] Park, S. (2016). India's jumbled trade policy. East Asia Forum. Retrieved 3 September 2017, from http://www.eastasiaforum.org/2016/01/30/indias-jumbled-trade-policy/

[31] Roy, J., \& Domínguez, R. (2005). The European Union and regional integration: A Comparative Perspective and Lessons for the Americas. Miami: Jean Monnet Chair, University of Miami, Europan Commission.

[32] Simms, B. (2014). Europe: The Struggle for Supremacy, 1453 to the Present. London: Penguin Books.

[33] Steans, J., Pettiford, L., Diez, T., \& El-Anis, I. (2010). An Introduction to International Relations Theory: Perspectives and Themes (3rd ed.). Harlow, Essex: Pearson Education Limited.

[34] Tangkitvanich, S., \& Rattanakhamfu, S. (2017). Assessing the ASEAN Economic Community. East Asia Forum. Retrieved 27 August 2017, from http://www.eastasiaforum.org/2017/03/21/assessing-the-asean-economiccommunityl

[35] Waldmeir, P., \& Donnan, S. (2017). Donald Trump signs 'Buy American, Hire American' order. Financial Times. Retrieved from https://www.ft.com/content/fa3f6cc4-246e-11e7-8691-d5f7e0cd0a16

[36] Willetts, D. (2017). HERE COME THE BIG GUNS: British tanks and heavy artillery arrive in Estonia to ward off Russian aggression. The Sun. Retrieved from https://www.thesun.co.uk/news/3156323/british-tanks-andheavy-artillery-arrive-in-estonia-to-ward-off-russian-aggression/

[37] Zaman, R. (2017). Can Bangladesh turn its burdensome geography into a blessing?. East Asia Forum. Retrieved 1 September 2017, from http://www.eastasiaforum.org/2017/09/01/can-bangladesh-turn-itsburdensome-geography-into-a-blessing/ 